\title{
SPECIFIC POLYMORPHISM 4G/5G GENE FOR PAI-1 AS A POSSIBLE CAUSE OF CEREBRAL VENOUS THROMBOSIS: \\ A CASE REPORT
}

Tatjana Boskovic Matic ${ }^{1,2}$, Aleksandar Gavrilovic ${ }^{1,2}$, Snezana Simovic ${ }^{1}$, Dejan Aleksic ${ }^{1}$, Katarina Vesic ${ }^{1}$, Ana Azanjac ${ }^{1}$

Slavco Toncev ${ }^{1,2}$, Svetlana Miletic Drakulic ${ }^{1,2}$

${ }^{1}$ Clinical Centre Kragujevac,Clinic for Neurology

${ }^{2}$ Faculty of Medical Sciences, University of Kragujevac

\author{
SPECIFIČNI POLIMORFIZAM 4G/5G GENA ZA PAI-1 IAO \\ MOGUĆI UZROK CEREBRALNE VENSIKE TROMBOZE: \\ PRIKAZ SLUČAJA \\ Tatjana Bošković Matić ${ }^{1,2}$, Aleksandar Gavrilović ${ }^{1,2}$, Snežana Simović1 ${ }^{\text {, Dejan Aleksić }{ }^{1} \text {, Katarina Vesić }{ }^{1}, \text { Ana } \text { Azanjac }}{ }^{1}$ \\ Slavčo Tončev ${ }^{1,2}$, Svetlana Miletić Drakulić' ${ }^{1,}$ \\ Klinički Centar Kragujevac,Klinika za neurologiju \\ Fakultet medicinskih nauka, Univerzitet u Kragujevcu
}

Received / Primljen: 21. 03. 2016.

Accepted / Prihvaćen: 28. 05. 2016.

\begin{abstract}
Thrombosis of veins and venous sinus (CVT) is the rare cerebral vascular disorder which makes less than 1\% of all strokes. Thrombosis of veins and venous sinuses is picturesquely called "Major neurological forger" since it is characterized by very varied clinical picture. Among the various causes of CVT, which can be of infective or non-infective nature, the congenital hyper coagulations especially stand out, diagnosis is based on highly sophisticated diagnostic tests.

We present the case of a female patient, 36 years old, who was hospitalized at the Clinic for Neurology in Clinical Center because of the diffuse headache she had for the last few days, with milder right-sided hemiparesis and one generalized tonic-clonic epileptic seizure. With nuclear magnetic resonance (MR/2D venography) the thrombosis of the upper and lower sagittal sinuses is confirmed. By appropriate laboratory tests, as well as by confirmatory immunological and genetic analyses, the impact of the most of the factors is excluded which can contribute to the occurrence of venous thrombosis. The only pathological findings which indicated the possible congenital thrombophilia as the cause of the sagittal sinus thrombosis was the determination of the specific polymorphism of the 4G/5G gene for plasminogen activator inhibitor 1.

According to our knowledge, this is the first decribed case of the possible impact of the specific polymorphism of the $4 G / 5 G$ gene for plasminogen activator inhibitor of 1 on the development of cerebral venous thrombosis.
\end{abstract}

Keywords: thrombosis of sagittal sinus; thrombophilia; polymorphism 4G/5G gene for PAI- 1

\section{SAŽETAK}

Tromboza vena $i$ venskih sinusa (CVT) predstavlja redak cerebrovaskularni poremećaj koji cini manje od 1\% svih moždanih udara. Tromboza vena $i$ venskih sinusa slikovito je nazvana „velikim neurološkim falsifikatorom"s obzirom da se odlikuje veoma raznolikom klinickom slikom. Medju brojnim uzrocima CVT, koji mogu biti infektivne i neinfektivne prirode, posebno se izdvajaju urodjene hiperkoaguloptije, cija dijagnoza se zasniva na visoko sofisticiranim dijagnostickim testovima.

Prikazujemo pacijentkinju, staru 36 godina, koja je hospitalizovana na Klinici za neurologiju KC zbog difuzne glavobolje unazad nekoliko dana, blaže desnostrane hemipareze $i$ jednog generalizovanog tonicno-klonicnog epilepticnog napada. Nuklearnom magnetnom rezonancom (MR/2D venografija) dokazana je tromboza gornjeg i donjeg sagitalnog sinusa. Odgovarajucim orjentacionim laboratorijskim testovima, kao i potvrdnim imunoloskim i genetickim analizama, iskljucen je uticaj vecine faktora koji mogu doprineti nastanku venskih tromboza. Jedini patoloski nalaz koji je upucivao na mogucu urodjenu trombofiliju kao uzrok tromboze sagitalnih sinusa bio je utvrdjivanje specificnog polimorfizma 4G/5G gena za inhibitor aktivatora plazminogena 1.

Prema nasim saznanjima, ovo je prvi opisani slučaj mogućeg uticaja specificnog polimorfizma 4G/5G gena za inhibitor aktivatora plazminogena 1 na razvoj cerebralne venske tromboze.

Ključne reči: tromboza sagitalnog sinusa; trombofilija; polimorfizma 4G/5G gena za PAI-1. 


\section{INTRODUCTION}

Thrombosis of veins and venous sinuses (CVT) is a rare cerebrovascular disorder which makes less than $1 \%$ of all strokes (1). With the adult patients there is an incidence of 3-4 cases per million (1), while in pediatric population it is bigger and it numbers 7 cases per million children per year (2). This disorder is associated with the high risk of death outcome and significant rate of consequent mental disability. In addition, the distinctive variability concerning etiology and clinical manifestation, as well as disagreement in the approach of medical treatment, ranked CVT in the group of important public health problems, which is worldwide, even today, the real challenge from the diagnostic and therapy standpoint.

One of the most significant causes of CVT are congenital and acquired thrombophilia that occur at $29 \%$ of patients, $22 \%$ of which are hereditary hyper coagulate states (3). Congenital thrombophilia have particular importance from the diagnostic aspect, where genetic deficit of antithrombin III and protein $\mathrm{C}$ and $\mathrm{S}$ and also mutation of G169A factor of $\mathrm{V}$ coagulation (FV Leiden), gene for prothrombin (FII G20210A) and gene for methylenetetrahydrofolate reductase (MTHFR C677T), in earlier studies were identified as independent risk factors for the occurrence of CVT $(3,4)$. On the other hand, for prothrombotic state due to genetic mutations in the plasminogen activator inhibitor 1 (PAI-1) there are no solid written evidence about the connection of such a disorder with risk of CVT, depending on polymorphism promoter region of PAI-1 gene.

In this case we present a young adult female patient with the thrombosis of sagittal venous sinus, who is confirmed to have the mutation of gene for PAI $15 \mathrm{G} / 4 \mathrm{G}$.

\section{CASE REPORT}

A female patient, 36 years old, was admitted in May 2015, at 6:50 PM at the Clinic of Neurology, Clinical Center Kragujevac, where she was sent from a regional hospital in Kosovska Mitrovica for the diffuse headache she had suffered for the past few days and one generalized tonic-clonic epileptic (GTC) seizure in the morning hours on the day of admission.

On admittance to our clinic, the patient was conscious, oriented, with stable vital parameters and with the finding of blood glucose in capillary blood $(7,2 \mathrm{mmol} / \mathrm{l})$ and the tongue bite as a confirmation of a previous epileptic seizure. In the neurological examination right-sided hemiparesis of the lower level was recorded with the score 5 on the National Institute of Health Stroke Scale (NIHSS).

In the personal anamnesis, the patient denied previous acute and other chronic diseases of importance. She had had three regular pregnancies with natural childbirths with no complications. She also denied diseases of hereditary significance.
Two more GTC seizures were observed right after the admittance of the patient. Computerized tomography of endo-cranium (CT) was initially performed where no pathological changes supratentorial and infratentorial were noticed. Anti-edematous therapy was immediately administered (Mannitol 20\%, $125 \mathrm{ml} / 6$ hours), anti-epileptic (Diazepam, intravenously, $10 \mathrm{mg}$ and tablets of Natrium-valproate in a fixed combination with valproic acid (333mg+145mg), daily dose $250 \mathrm{mg} / 12$ hours) and antiaggregation therapy (100mg acetylsalicylic acid/24 hours). After that, the cardiologist was consulted who registered normal findings of the observed physiological systems. Basic laboratory analyses were made (complete blood test, Creactive protein, glucose, urea, creatinine, jonogram) with the results within the limits of reference values.

The next morning, the patient was examined by magnetic resonance (MR cranial, MR venography and MR 2D venography) which confirmed the thrombosis of the upper and lower sagittal sinus, while high left in parietal lobe the signs of sub-acute ischemic lesions with hemorrhagic transformation were registered.

The second day of hospitalization, after the above mentioned additional radiological examinations, the therapy was changed in the sense that the suspended use of doze of acetylsalicylic acid and low molecular heparin, enoxaparin, in therapy doze $0,6 \mathrm{mg} / 12$ hours, subcutaneously) was added. During the controlling neurological examination right-sided weakness persisted with the identical NIHSS as at the admittance to the hospital.

On the fifth day of hospitalization anti-edematous therapy was excluded and the appliance of anti-epileptics, natrium-valproate in the fixed combination with valproic acid was continued through the full therapeutic dose (500mg/12 hours).

During the further hospitalization ultrasound heart examination was done as well as color Doppler-sonography (CDS) of main neck arteries with positive results recorded.

Further laboratory tests were carried out with the aim to examine the cause of thrombosis, which meant to eliminate potential immunological and infective causes of a new neurological disorder: prothrombin and activated partial thromboplastin time were measured, concentration of D dimer and fibrin monomers, the activity of anti-thrombin and anticoagulant proteins $C$ and $S$, the level of homocysteine, coagulation test with diluted Rusell's snake poison, lupus anticoagulant, activity and concentration of vonWilebrand's factor and the activity of coagulation factors II, V and VIII; also the level of immunoglobulin types G, M and $\mathrm{A}$, activity of $\mathrm{C} 3$ and $\mathrm{C} 4$ components of complement, titer of anti-nucleus, anti-mitochondrial and anti-smooth muscles antibodies, then concentration of the surface antigen of hepatitis $\mathrm{B}$ virus and the titer of specific antibodies against hepatitis $C$ virus, HIV virus, Epstein-Bar virus and Borrelia Burgdorferi; the results of all listed analyses were normaland the tolerances without clinical importance.

In order to additionally examine etiology of thrombosis, genetic searches were carried out also (real time PCR) 
to thrombophilia, which didn't confirm the mutation of gene for prothrombin (FII G20210A), factor V coagulation (FV Leiden) and methylenetetrahydrofolate reductase (MTHFR C677T), while simultaneously the existence of specific polymorphism 4G/5G(locus-675) in promote region PAI-1 gene was confirmed.

After two weeks of hospitalization, total regression of neurological deficit occurred and the patient didn't have epileptic seizures any more.

On discharge, instead of low molecular heparin, peroral anti-coagulant prophylaxis was added as therapy, tablets of dabigatran $150 \mathrm{mg} / 12$ hours, with previously administered anti-epileptic therapy. During the routine three-month control tests after the discharge from the hospital, no neurological deficit was detected with the patient, she didn't have epileptic seizures, she was taking prescribed therapy regularly and she took it well.

\section{DISCUSSION}

Thrombosis of veins and venous sinus is picturesquely called "major neurological forger" considering that it is characterized by very diverse clinical picture. This disorder is noticed mainly with the persons younger than 50 (at about $80 \%$ ), whereby $75 \%$ of cases are women (5). It is often manifested by headache (6), eyesight disturbances (7), epileptic seizures (8), consciousness disorder and focal neurological deficit as well as specific symptoms depending on the localization of pathological process. When the thrombosis of sagittal sinuses is suspected according to the clinical picture, properly set diagnosis requires complete evaluation by neuro-visualization methods as CT or MR venography depending on availability and characteristics of the patient, which present the "golden standard" for the confirmation of this disorder (1). Our patient according to all demographic and clinical standards presents the typical example of CVT, for whom due to the inability of adequate CT confirmation, diagnosis of thrombosis of the upper sagittal sinus was set by MR venography.

Among various causes of CVT, which can be of infective (sinusitis, otitis media, meningitis, system infections,etc) or non-infective nature (trauma, brain tumors, certain neurosurgical procedures, hematological malignancies, pregnancy and postpartum period, consuming of some medications, chronic inflammatory bowels diseases, system diseases of connective tissue, nephritic syndrome, cirrhosis of the liver,etc), congenital hyper coagulopathy stands out, it's diagnosis is based on highly sophisticated diagnostic tests (9). In the case of our patient, with appropriate laboratory tests, positive immunological and genetic analyses, disorders at the level and activity of the most factors which can influence the occurrence of vein thromboses, (prothrombine, anti-thrombin, anti-coagulation proteins $\mathrm{C}$ and $\mathrm{S}$, factor $\mathrm{V}$ coagulation, methylenetetrahydrofolate reductase enzyme, anti-phospholipid antibodies,etc) were excluded while the determination of the specific polymorphism 4G/5G gene for PAI-1 was the only pathological result which indicated to the possible congenital thrombophilia.

Plasminogen activator inhibitor type 1 is an endogenous glycoprotein from the group of serine proteases, which is produced in endothelial cells, liver cells, fat, etc. (10) In the human body acts as the main inhibitor of a tissue plasminogen activator and urokinase, as a result of which a suppression of fibrinolytic activity occurs. (11) Its synthesis is regulated by the gene on chromosome 7 in whose promoter region at position $-675 \mathrm{bp}$ mutation is described which results in heterozygous variant of $4 \mathrm{G} / 5 \mathrm{G}$, with the $4 G$ only transcriptionally active allelic variants responsible for increasing levels of PAI-1 in plasma, thus generally increases the risk of thrombosis (12). A recent study in a population of patients in Serbia showed that the frequency of this polymorphism is the most frequent, with an incidence of slightly more than $46 \%$, while the recorded prevalence of allelic variants of homozygous $4 \mathrm{G} / 4 \mathrm{G}$ and $5 \mathrm{G} / 5 \mathrm{G}$ was quite a range of about $36 \%$, or $19 \%$ (13).

According to previous studies, the effect of heterozygous variants of $4 \mathrm{G} / 5 \mathrm{G}$ PAI-1 gene on the formation of arterial or venous thromboembolic complications is controversial. In fact, there is evidence that the presence of the $4 \mathrm{G} / 5 \mathrm{G}$ polymorphism of PAI-1 can significantly increase the risk of coronary ischemic disease (14), including myocardial infarct (15), and venous thromboembolism $(16,17)$, while on the other hand, there are data indicating the absence of any connection between the genotypic variants with the aforementioned unwanted outcomes $(18,19)$. In addition, it was shown that in most cases the contribution of PAI-1 4G/5G polymorphism of the synergetic conditioned by the presence of other congenital and/or acquired conventional risk factors for the occurrence of arterial, and venous thrombosis, such as hypertension, diabetic disease, obesity, malignant diseases, chronic inflammatory diseases, hereditary hyper coagulopathy and similar (1-4), which also can have a significant impact on the level of PAI-1 in plasma. In contrast, none of the previous studies have established significant connection 4G/5G genotype and ischemic stroke $(20,21)$. Moreover, in contrast to the thrombosis of the coronary arteries which is dominated by allelic variant $4 \mathrm{G}$ with the increase of PAI-1 in plasma, cerebral artery thrombosis is significantly associated only with the homozygous genotype $5 \mathrm{G} / 5 \mathrm{G}$, accompanied by a reduced plasma levels of PAI-1 (8). This paradox suggests that specific polymorphism 4G/5G PAI-1 gene does not affect the mechanisms of cardiovascular risk solely dependent on the level of PAI-1 in plasma (8). When it comes to CVT, according to our knowledge so far only one type has been carried out of observational study "case-control", which has not shown that allelic variant of 4G/5G PAI-1 gene significantly affects the risk of this disorder, unlike mutations of prothrombin G20210A (22). 
Additionally, the PAI-1 4G/5G polymorphism was associated with the risk of the numerous and varied other clinical disorders such as diabetic mellitus and its chronic complications (23, 24), recurrent miscarriage (25), preeclampsia (26), polycystic ovary syndrome (27), bronchial asthma (28), cancer (especially colon and endometrium) (29), sepsis (including fatal outcome as a result) (30) etc, where due to unreconciled opinions, further studies on this are carried out intensively.

\section{CONCLUSION:}

In the case of our patient the available screening and confirmatory diagnostic tests excluded all other potential causes of venous sinus thrombosis. To our knowledge,this is the first described patient with the history of specific polymorphism 4G/5G (locus-675) in the promoter region of PAI-1 gene isolated a possible cause of thrombosis of the sagittal sinus, which should be confirmed in future prospective studies of adequate design.

\section{REFERENCE}

1. Einhäupl K, Bousser MG, de Bruijn SF et al. (2006). EFNS guideline on the treatment of cerebral venous and sinus thrombosis. Eur J Neurol. 13 (6), 553-9.

2. deVeber G, Andrew M, Adams C et al. (2001). Cerebral sinovenous thrombosis in children. N Engl J Med. 345 (6), 417-23.

3. Wysokinska EM, Wysokinski WE, Brown RD et al. (2008). Thrombophilia differences in cerebral venous sinus and lower extremity deep venous thrombosis. Neurology. 19;70(8), 627-33.

4. Saadatnia M, Salehi M, Movahedian A et al (2015). Factor V Leiden, factor V Cambridge, factor II GA20210, and methylenetetrahydrofolate reductase in cerebral venous and sinus thrombosis: A case-control study. J Res Med Sci. 20 (6), 554-562.

5. Countinho JM, Ferro JM, Canhão P et al. (2009). Cerebral Venous and Sinus Thrombosis in Women. Stroke. 40(7), 2356-2361.

6. Flores-Barragan JM, Hernandez-Gonzalez A, GallardoAlcaniz MJ et al. (2009). Clinical and therapeutic heterogeneity of cerebral venous thrombosis: a description of a series of 20 cases. Rev Neurol. 49(11), 573-6.

7. Purvin VA, Trobe JD, Kosmorsky G. (1995). Neuroophthalmic features of cerebral venous obstruction. Arch Neurol. 52(9), 880-885.

8. Ferro JM, Canhão P, Bousser MG et al. (2008). Early seizures in cerebral vein and dural sinus thrombosis: risk factors and role of antiepileptics. Stroke. 39(4), 1152-1158.

9. Alvis-Miranda HR, Milena Castellar-Leones S, AlcalaCerra $G$ et al. (2013). Cerebral sinus venous thrombosis. J Neurosci Rural Pract. 4(4), 427-438.
10. Mehta R, Shapiro AD. (2008). Plasminogen activator inhibitor type 1 deficiency. Haemophilia. 14(6), 1255-60.

11. Lee C.C, Tze-Sing H. (2005). Plasminogen Activator Inhibitor-1: The Expression, Biological Functions, and Effects on Tumorigenesis and Tumor Cell Adhesion and Migration. J Cancer Mol. 1(1), 25-36.

12. Yasar Yildiz S, Kuru P, ToksoyOner E et al. (2014). Functional stability of plasminogen activator inhibitor-1. Scientific World Journal. 2014:858293.

13. Đorđević V, Gvozdenov M, Pruner I et al. (2013). Učestalost PAI-1 4G/5Ggenske varijante u srpskoj populaciji. Medicinski glasnik Specijalna bolnica za bolesti štitaste žlezde I bolesti metabolizma Zlatibor. 18 (49), 28-41.

14. Zhang H, Dong P, Yang X et al. (2014). Plasminogen activator inhibitor-1 4G/5G polymorphism is associated with coronary artery disease risk: a meta-analysis. Int J ClinExp Med. 7(10), 3777-3788.

15. Parpugga TK, Tatarunas V, Skipskis V et al (2015). The Effect of PAI-1 4G/5G Polymorphism and Clinical Factors on Coronary Artery Occlusion in Myocardial Infarction. Dis Markers. 2015:260101.

16. Wang J, Wang C, Chen $\mathrm{N}$ et al. (2014). Association between the plasminogen activator inhibitor-1 4G/5G polymorphism and risk of venous thromboembolism: a meta-analysis. Thromb Res. 134(6), 1241-8.

17. Gohil R, Peck G, Sharma P. (2009). The genetics of venous thromboembolism.A meta-analysis involving approximately 120,000 cases and 180,000 controls. Thromb Haemost. 102(2), 360-70.

18. Doggen CJ, Bertina RM, Cats VM et al. (1999).The $4 \mathrm{G} / 5 \mathrm{G}$ polymorphism in the plasminogen activator inhibitor-1 gene is not associated with myocardial infarction. Thromb Haemost. 82(1), 115-20.

19. Chen YL, Zhang JX, Wang PX et al. (2005).Association of $4 \mathrm{G} / 5 \mathrm{G}$ polymorphism in PAI1 promoter with PAI1 level in deep vein thrombosis. Zhonghua Yi Xue Yi ChuanXue Za Zhi. 22(6), 624-7.

20. Tsantes AE, Nikolopoulos GK, Bagos PG et al. (2007). Plasminogen activator inhibitor-1 4G/5G polymorphism and risk of ischemic stroke: a meta-analysis. Blood Coagul Fibrinolysis. 18(5), 497-504.

21. Bentley P, Peck G, Smeeth L et al. (2010). Causal Relationship of Susceptibility Genes to Ischemic Stroke: Comparison to Ischemic Heart Disease and Biochemical Determinants. PLoS ONE. 5(2), e9136.

22. Ringelstein M, Jung A, Berger K et al. (2012). Promotor polymorphisms of plasminogen activator inhibitor-1 and other thrombophilic genotypes in cerebral venous thrombosis: a case-control study in adults. J Neurol. 259(11), 2287-92.

23. Xu F, Liu H, Sun Y. (2016). Association of plasminogen activator inhibitor-1 gene polymorphism and type 2 diabetic nephropathy. Ren Fail. 38(1), 157-62.

24. Xu K, Liu X, Yang F et al. (2013). PAI-1 -675 4G/5G polymorphism in association with diabetes and diabetic complications susceptibility: a meta-analysis study. PLoS One. 8(11), e79150. 
25. Li X, Liu Y, Zhang R et al. (2015). Meta-analysis of the association between plasminogen activator inhibitor-1 4G/5G polymorphism and recurrent pregnancy loss. Med SciMonit. 21, 1051-6.

26. Morgan JA, Bombell S, McGuire W. (2013). Association of plasminogen activator inhibitor-type 1 (-675 4G/5G) polymorphism with pre-eclampsia: systematic review. PLoS One. 8(2), e56907.

27. Lee YH, Song GG. (2014). Plasminogen activator inhibitor-1 4G/5G and the MTHFR 677C/T polymorphisms and susceptibility to polycystic ovary syndrome: a metaanalysis. Eur J Obstet Gynecol Reprod Biol. 175:8-14.
28. Nie W, Li B, Xiu QY. (2012). The -675 4G/5G polymorphism in plasminogen activator inhibitor-1 gene is associated with risk of asthma: a meta-analysis. PLoS One. 7(3), e34385.

29. Li L, Nie W, Zhou H et al. (2013). Association between plasminogen activator inhibitor-1 -675 4G/5G polymorphism and sepsis: a meta-analysis. PLoS One. 8(1), e54883.

30. Reshetniak TM, Ostriakova EV, Patrusheva NL et al. (2013). Plasminogen activator inhibitor type 1 gene polymorphism and thromboses in patients with antiphospholipid syndrome. TerArkh. 85(1), 76-84. 